\title{
CONDYLOGRAPHIC RECORDING OF MASTICATORY FUNCTION: EXPLORATIVE STUDY ON OCCLUSAL PARAMETERS AND CHEWING PERFORMANCE WITH NATURAL FOOD AND A STANDARD FOOD MODEL
}

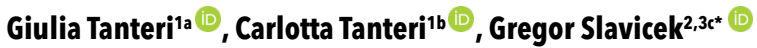 \\ 'Private Practice - Studio Tanteri, Turin, Italy; \\ ${ }^{2}$ Steinbeis Transfer Institute Biomedical Interdisciplinary Dentistry, Steinbeis University Berlin, DE-12489 Berlin, Germany; \\ ${ }^{3}$ OREHAB-Minds GmbH, DE-70567 Stuttgart, Germany \\ aMD, MSc, Specialist in Maxillofacial Surgery; e-mail: tanteri@tanteri.it; ORCIDiD: https://orcid-org/0000-0002-3765-7722 \\ bDDS, MSc; e-mail: carlottatanteri@gmail.com; ORCIDiD: https://orcidorg/0000-0001-5560-5574 \\ CMD, DDS, MSc, Director and Head, CE0 and Head; e-mail: gregorslavicek@stw.de; 0RCIDiD: https://orcidorg/0000-0003-2454-4048
}

d) https://doi.org/10.25241/stomaeduj.2021.8(1).art. 6

Introduction Loss of teeth defines oral health status and chewing abilities. Caries and periodontal disease have been associated with systemic diseases, however they may contribute to cognitive impairment too. Mastication assessment appears to possess broad significance, and is needed to create background knowledge for chewing harmony. The aim of this study was to evaluate chewing performance and the characteristics of condylographic recordings, during mastication of Natural Food (NF) and a Standard Food Model (SFM), in subjects with different occlusal parameters.

Methodology Twenty-three adult subjects' mastication was assessed with a standardized recording protocol, when chewing onto SFM and NF in three different textures. Detailed occlusal characteristics, condylographic recording data and condylographic patterns during mastication were all analyzed and compared.

Results Bilateral Crossbites, Missing Molars and Asymmetric Molar Class were related to higher disharmony and transversal displacement during chewing. Missing and unreplaced molars showed dysfunctional patterns and so did worn out occlusal surfaces. Molar Class alone did not prove to be a useful predictor in chewing test results.

Conclusion Increasing evidence indicates that oral health has an impact on Individual and Public Health. It is important to understand that oral health and its functional status are to be maintained during one's lifetime, and that preventive, therapeutic measures at all ages should have a common functional target to grant neurobiological health as well as nutritional goals of Mastication. Further studies are needed to better understand the relevance of additional parameters such as Occlusal Plane Inclination, Curve of Spee, and three-dimensional asymmetries.

\section{KEYWORDS}

Mastication; Condylography; Axiography; Chewing Test; Occlusion.

\section{INTRODUCTION}

Throughout the history of medicine Mastication has triggered the interest of researchers due to its complexity, its functions and behavioral significance. Mastication is the process by which food is broken down by teeth into smaller pieces, mixed with saliva into a bolus and made suitable for swallowing. The quality of mastication and its efficiency are crucial even beyond the individual ability to perform chewing strokes and to swallow. Oral health has been held responsible for, or related to, a number of systemic conditions. For instance, poor oral health has been investigated in the past as an independent risk factor and association for systemic diseases such as myocardial infarction, coronary disease and

(c) (1) (3) OPEN ACCESS This is an Open Access article under the CC BY-NC 4.0 license. Peer-Reviewed Article

Citation: Tanteri G, Tanteri C, Slavicek G. Condylographic recording of masticatory function: explorative study on occlusal parameters and chewing performance with natural food and a standard food model. Stoma Edu J. 2021;8(1):52-64

Received: February 21, 2021; Revised: February 27, 2021; Accepted: March 02, 2021; Published: March 04, 2021

*Corresponding author: Dr. Gregor Slavicek, MD, DDS, MSc, Director and Head, CEO and Head OREHAB-Minds GmbH, Zettachring 2, DE-70567

Stuttgart, Germany

Tel./Fax: +49-7307-24922-11; e-mail: g.slavicek@orehab-minds.com

Copyright: $\odot 2021$ the Editorial Council for the Stomatology Edu Journal. 


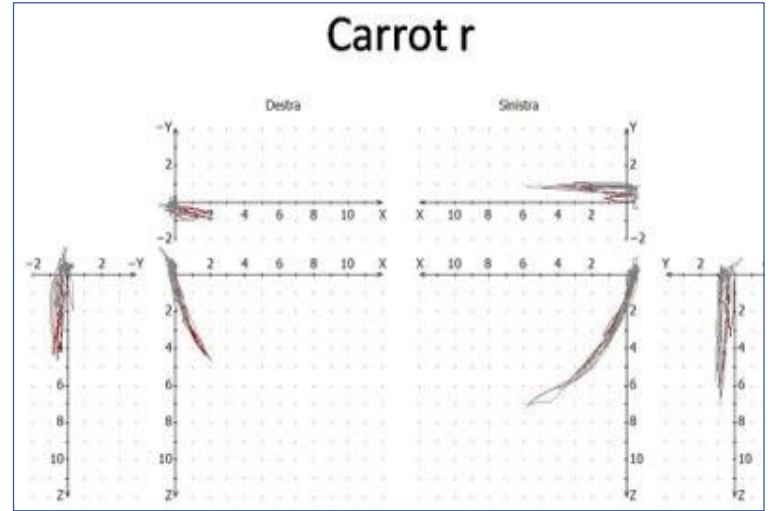

Figure 1. Expected chewing pattern - example of right side chewing of NF Carrot: ws displays shorter and steeper tracings as opposed to nws. Movement is harmonic and superimposable, transversal aspects of movement are contained.

ITable 1. Inclusion criteria.

\begin{tabular}{|l|}
\hline Inclusion criteria \\
\hline $\begin{array}{l}\text { Subjects were considered for the study if the following } \\
\text { conditions were met: }\end{array}$ \\
\hline - any Gender \\
\hline $\begin{array}{l}\text { - good overall health status (no prescription drugs taken } \\
\text { routinely, asymptomatic) }\end{array}$ \\
\hline - no previous diagnosis of Temporomandibular Disorder \\
\hline $\begin{array}{l}\text { - willingness to understand the procedure and give informed } \\
\text { consent }\end{array}$ \\
\hline
\end{tabular}

diabetes [1-3]. This whole issue has reached a higher and wider awareness only in recent times, although earlier studies concerning these associations had already highlighted the importance of maintaining a satisfactory oral and dental status for the good of systemic health and for the consequences on Public Health [4]. Among the above-mentioned conditions, Dementia has more recently been related to oral health and chewing impairment. Because of its vigorous onset in the elderly populations, and because the world population is more and more represented by the elder age group, Dementia has become an increasingly important health and socioeconomic issue [5].

It is fair to understand that, among other factors, the mere number of lost teeth defines not only one's oral health status, but also his/her chewing abilities, with subsequent forceful changes in diet, malnutrition, and an inflammatory response which have all been related to an increased risk of Dementia and Alzheimer's Disease (AD). These emerging findings, besides harmony and good functioning of the stomatognathic system, call for further studies on mastication and on the significance of lost teeth, both for what concerns the number of missing teeth and what dental element in particular [6]. Teeth possess discrimination for direction of forces, texture and hardness of foods, thanks to the interaction between pulp-dentine-enamel units and periodontal ligaments $[7,8]$. Studying mastication and the stomatognathic system has shown to be a

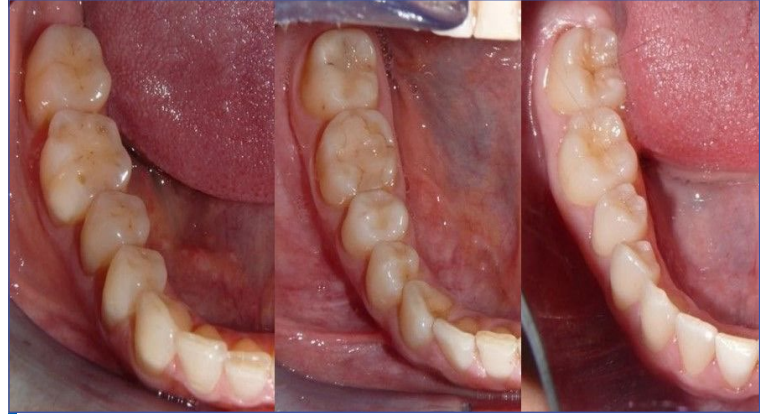

Figure 2. Quality of occlusal surfaces, from left to right: poor, average, good.

hard and demanding quest which proceeded along with the development of ad hoc apparatuses and recording devices. Studies by Lundeen and Gibbs from the 1980s showed that there are differences in chewing in relation to growth, and that they are related to changes in form and function which take place during transition from infancy to adulthood (increase in the steepness of the articular eminence, development of the anterior tooth guidance, and change from deciduous to permanent teeth). Adults' chewing pattern has a midsagittal opening and wide lateral closing movements when observed from a dental perspective $[9,10]$. The quality of the occlusion, conditions such as Temporomandibular Disorders (TMJ) and interferences in occlusion all affect mastication: the more the interferences the longer the chewing time and the more atypical the pattern looks [11]. Regarding patterns, Lundeen and Gibbs studied mastication with the Replicator System $[9,10]$. The Replicator System was an electronic jawmovement recorder that allowed to replicate all border and chewing movements while also being able to examine 'chewing casts' from all views. The authors' evaluations of the chewing patterns were made on occlusal points (first molars and interincisal), on both sides, as well as by tracking the joints.

Studies concerning the masticatory patterns have been described in previous works, the most notable being the ones with the Sirognathograph first, and the Kinesiograph later on. This latter method can only identify movement of a single anterior point with a magnet positioned on the lower arch, but it has the possibility to study muscular activity through Electromyography at the same time $[12,13]$.

Researchers have also recognized a repetition and reproducibility of chewing patterns, with harmony also being a characteristic of a healthy chewing function and, if harmony is missing, along with repetition and a scheme, then a dysfunctional mastication is observed. Malocclusions such as unilateral crossbite have shown a peculiar subversion of opening and closing direction which are substantially different to the expected chewing pattern: in these 
Table 2. Exclusion criteria.

\begin{tabular}{|l|}
\hline Exclusion criteria \\
\hline Subjects were excluded if the following conditions were met: \\
\hline - age below 18 \\
\hline - age above 70 \\
\hline - food allergy (nuts) \\
\hline - vegetarian/vegan subjects \\
\hline - hyperglycemia/diabetes \\
\hline - permanence of deciduous teeth \\
\hline - removable total/partial prostheses \\
\hline - ongoing orthodontic treatment \\
\hline - any dental extraction/dental surgery in the previous 6 months \\
\hline - composite/filling on occlusal surfaces in the previous 6 months \\
\hline - acute oral health issue (caries, odontogenic abscess, odontogenic phlegmon) \\
\hline - acute craniofacial issue (trauma with/without fractures) \\
\hline - acute/chronic pain of masticatory and facial muscles \\
\hline - primary headaches \\
\hline - chronic neck, shoulders or back pain (pain $>3$ months) \\
\hline - previous brain injuries \\
\hline - cleft palate/lips \\
\hline - facial clefts \\
\hline - impaired saliva production due to drugs or systemic disease \\
\hline - mental illness \\
\hline - visual impairments (sightless subjects) \\
\hline - neurological disorder with impaired motor capabilities with/without medication \\
\hline - neurological conditions affecting cranial nerves \\
\hline - any condition influencing proper informed consent to participation in the study \\
\hline - any conditioning affecting the sitting position in a dental chair \\
\hline
\end{tabular}

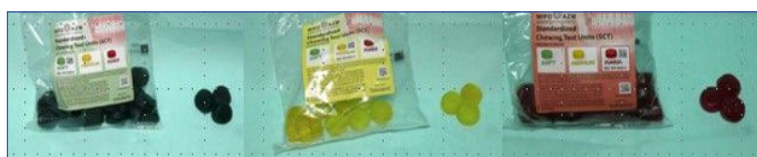

Figure 3. Standard Food Model jellies, from left to right: soft, medium and hard texture.

cases, the mandible will first move medially during opening and then laterally, so as to confront with the 'crossed' surfaces of antagonist teeth. Moreover, this altered pattern has a narrower width and a more vertical closing angle. If the 'Functional Matrix' of Moss is not to be forgotten, this supposedly has some effect on growing children, both structurally and with respect to motor control, and it is the reason why unilateral crossbite can be looked at as a 'neuromuscular syndrome' $[12,14]$.

Some studies have explored human mastication through chewing tests and their outcome. Kikui and colleagues for instance assessed comminution of a jelly, claiming that it was a valid method for gathering relevant information from the number of pieces and their surface area.

This better replicates in their opinion what actually occurs during effective chewing: crushing and an increase in the surface area of food, so as to facilitate reaction with digestive enzymes, decomposition, and the absorption of nutrients [15]. Some other tests use natural foods as a material test, however physical properties of natural foods vary and are difficult to standardize. There are natural variations in size and texture which produce differences in the final outcomes. Besides, hardness is not constant, due to the various degrees of water incorporation

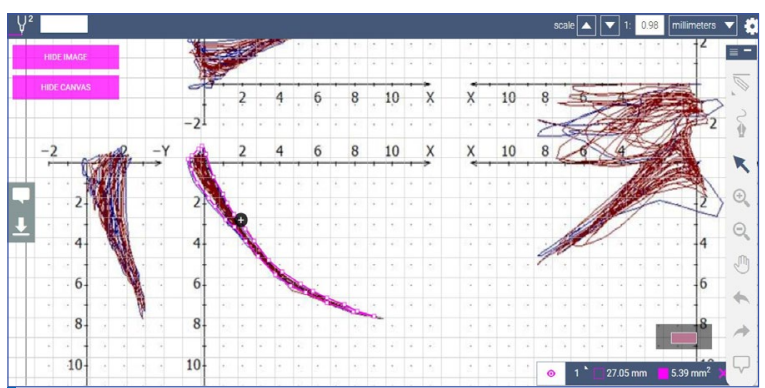

Figure 4. Tool for calculating areas of condylographic tracings in sagittal, cranial and frontal view. In this figure, the sagittal tracing was digitally outlined and in the bottom right-hand corner are the perimeter and the area of the right sagittal condylographic tracing. The same procedure was carried out for all planes (sagittal, cranial and frontal) on both sides for all chewing.

thus making the standardization for the masticatory tests difficult. Natural foods that are mostly described by authors are: peanuts, almonds, cocoa, carrots, hazelnuts, decaffeinated coffee beans and nuts [16-21]. Previous experience with the limitations of natural foods chewing tests brought about the need for an ideal food model for experimental, research and clinical testing. With this respect a Standard Food Model (SFM) was first developed, described and proposed by Slavicek in 2009 [22-26]. Such food model has been produced in a short cylindrical shape and three different hardnesses (A. Egger' Sohn, Süsswaren und Naturmittel GmbH., Mellergasse 4, A-1230 Vienna, Austria).

Condylography as a method for evaluating mandibular movements has its predecessors dating as back as the last decades of the 1800s. The first recordings were reported by Ulrich and Walker, and invaluable contributions to the study of hinge axis, Bennett movement, jaw tracking, articulator programming 
ITable 3. Condylographic data collected directly from the recording software.

Software-retrieved data for analysis of Mastication

Maximum displacement (s) of the hinge axis $(\mathrm{mm})$ for both the working side and the non-working side (ws and nws) assessed on the sagittal plane

Sagittal Condylar Inclination $\mathrm{SCl}^{\circ}$ (inclination of the hinge axis excursion) for both the working side and the non-working side (ws and nws)

ITable 4. Condylographic data calculated from tracings with the use of an additional tool.

\begin{tabular}{|l|}
\hline Calculations for analysis of Mastication \\
\hline Sagittal area for both working side and non-working side $\left(\mathrm{mm}^{2}\right)$ \\
\hline Transversal cranial area for both working side and non-working side $\left(\mathrm{mm}^{2}\right)$ \\
\hline Transversal frontal area for both working side and non-working side $\left(\mathrm{mm}^{2}\right)$ \\
\hline Ratio sagittal: cranial for both working side and non-working side \\
\hline Ratio sagittal: frontal for both working side and non-working side \\
\hline
\end{tabular}

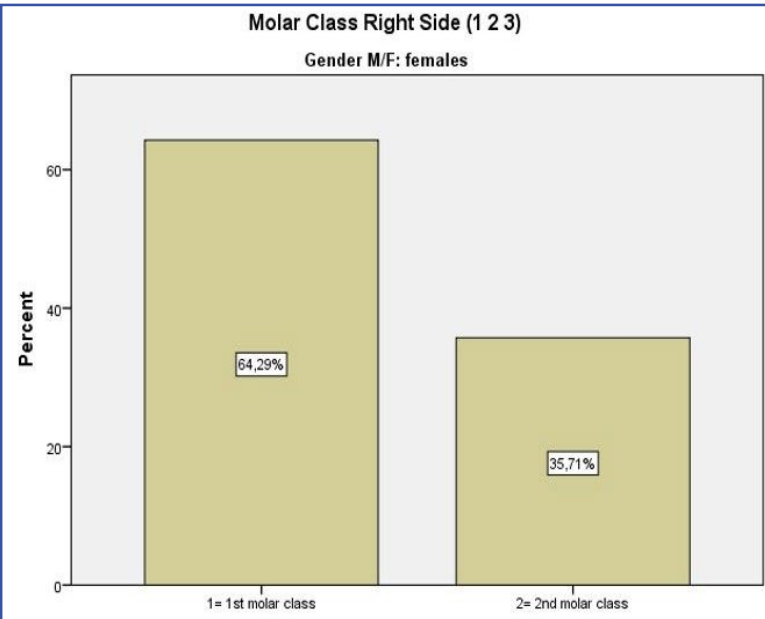

Molar Class Right Side (1 2 3)

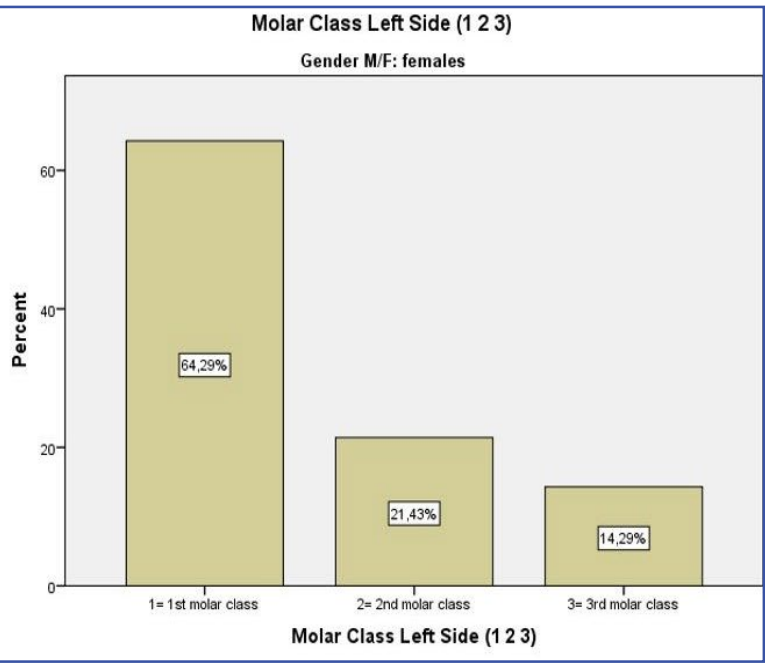

Figure 5. Molar Class Right and Left - Distribution Females.

and for diagnostic purposes have been made by Bennett, Eltner, Gysi, McCollum, Posselt, Messerman, Bewersdorff, Jankelson, Lundeen, Alsawaf, Missert and Slavicek [27].

Caries, periodontal disease and systemic conditions that can affect the periodontium, can all potentially lead to tooth loss. Tooth loss can somewhat be prevented and has therefore been the target for Public Health measures, but nevertheless it is still common, especially within the ageing population and in the lower socio-economic groups [28,29].

What is mostly unforeseen or prevented, but is just as common, is Dementia, the most frequent being Alzheimer's Disease (AD).

A World Health Organization report from 2013 stated that the total number of people with Dementia worldwide in 2010 was estimated at 35.6 million and is deemed to almost double every 20 years, to 65.7 million in 2030 and 115.4 million in 2050 [30]. $A D$ occurs because of environmental, genetic and vascular risk factors, yet nearly half of ADs do not have a clear mutation or cause [6]. A relationship between $A D$ and tooth loss has been sought for at least twenty years now, with publications focusing on the transition from memory impairment to $A D$, on oral health in nursing homes, cohort studies and community homes for the elderly [31-34]. This correlation had been hypothesized even earlier, when basic findings were retrieved highlighting the fact that Dementia patients were more likely to have a greater tooth loss $[35,36]$. However different studies and authors have aspired to study this relationship as a predisposing condition, similarly to what has been done with the correlation between cardiovascular disease and periodontitis. A 5-year prospective cohort study investigated the effect of tooth loss on the development of Mild Memory Impairment (MMI) among the elderly [31]. A study on identical twins revealed that major tooth loss before the age of 35 was a significant risk factor for AD [32]. A study on a population of nuns, found that 9 or fewer remaining teeth were associated with an increased risk of Dementia [33].

Type 2 Diabetes patients were the target of a prospective cohort study that showed that Dementia and cognitive decline are associated with having no teeth [37]. Conversely, the presence of teeth, or better, the preservation of natural teeth and cognitive functioning have shown a significant positive relationship [38]. Worse episodic memory has been assessed in other studies and it has been correlated with tooth number, too [39]. Okamoto and colleagues also reported about a survey study that claimed that patients with MMI will more 


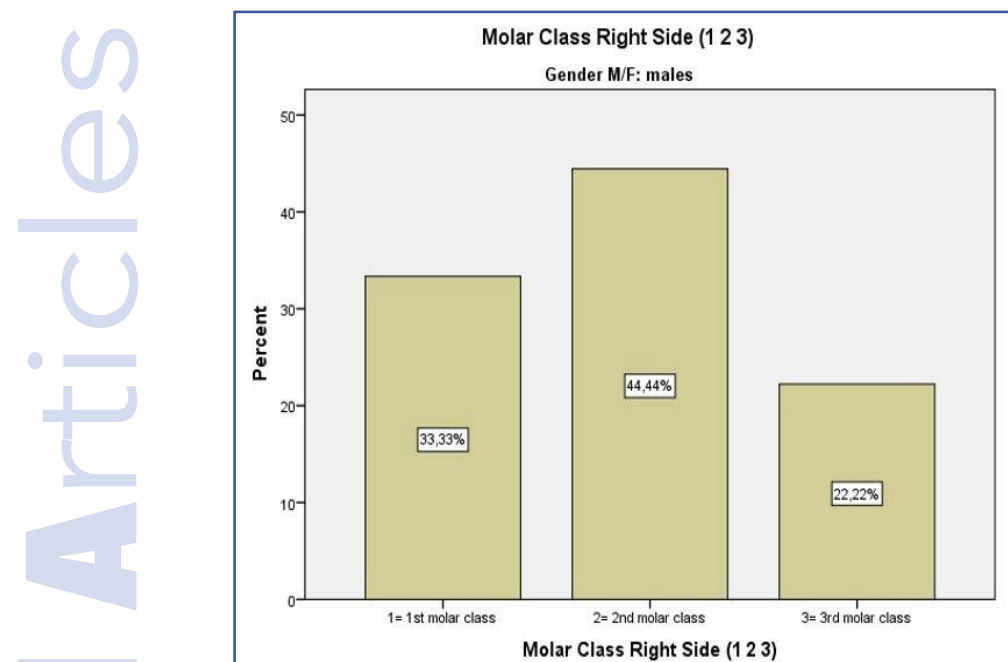

Figure 6. Molar Class Right and Left - Distribution Males.

likely progress into $A D$ as opposed to other types of dementia, thus making MMI (examined through the Mini-Mental State Examination - MMSE) a good time-frame for evaluations of this kind [40]. In the Fujiwara-kyo study a population of 3696 healthy residents over the age of 65 , was observed from 2007 to 2012. Among these, 2486 underwent followup examination and 2335 were included in the final analysis (only cognitively intact or MMI subjects). This very powerful and well-designed study showed that tooth loss and worse cognitive performance are indeed correlated, and that absence of tooth loss and preservation of the patients' baseline status meant no increase in risk of MMI [31].

Possible reasons for the association between memory disorder and tooth loss have been highlighted not only in the Fujiwara-kyo paper: the existence of an inflammatory status related to periodontal disease which caused tooth loss; genetic factors related to both MMI and periodontal disease; and a decrease in sensory receptors function. An observational study published in 2015 aimed at drawing some associations between tooth loss and Dementia from the late 1960s onwards [41].

The hypothesis behind this retrospective analysis of a cohort of women was that tooth loss was an expression of some proinflammatory activity and that there was a correlation between the number of teeth and Dementia. Mastication influences the activity in the cerebral cortex, stimulating cognitive function and preventing brain degradation. Rhythmic movements, and this may be one reason why sports have a similar beneficial effect, increase blood flow especially in the prefrontal cortex and the hippocampus, where learning and memory performance reside [31,38].

Thorough dissertation on the role of chewing, hippocampal, reticular formation and somatosensory associations is not the scope of this paper, however impoverishment of chewing abilities and function through alteration in number or quality of occlusal determinants (extraction or milling of molars) and a long-term soft-diet feeding, can inhibit learning

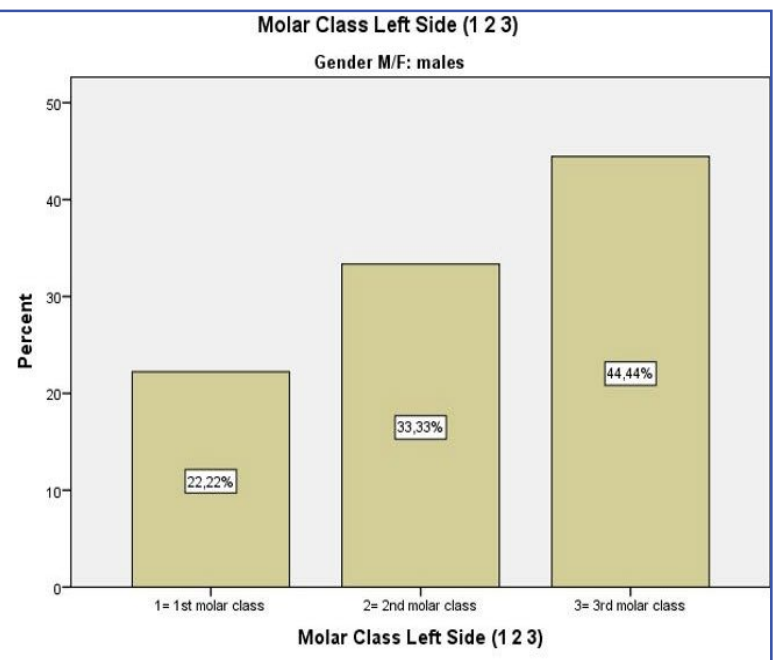

and memory [8,42-46]. A pilot study by Elsig allowed to point out a difference between the number of remaining teeth and chewing efficacy in Dementia patients, thus further encouraging the performance of routine chewing tests besides tooth count in geriatric evaluations [47]. Mastication and its study appear to possess significance both individually, in terms of prediction of disease or its risk, for its educational value, and in order to create a wider database for chewing patterns and unfavorable occlusal features, which will enable to fulfill the aforementioned purposes.

The aim of this study was to assess the characteristics of condylographic tracings, during mastication of natural food (NF) and a standard food model (SFM), in subjects with different occlusal parameters. Based on the existing literature, the purpose was to evaluate whether condylography was suitable for tracking mastication at the temporomandibular joint (TMJ), to evaluate whether condylography could reliably provide a clear tracing aspect working (ws) versus non-working side (nws) with the ws being steeper, straighter and shorter as opposed to the nws (see Fig. 1), if disharmony or subversion of the abovementioned aspect of ws and nws for some occlusal features (flat occlusal surfaces, missing teeth,...) and food properties.

\section{MATERIALS AND METHODS}

Twenty-three adult subjects' mastication was assessed by means of condylography with a standardized recording protocol, when chewing onto SFM and NF in three different textures (for SFM: hard, medium, soft; for NF: salad leaf, carrot slice, nut). The study protocol followed the ethical guidelines of the Declaration of Helsinki, and informed consent prior to recording was acquired from all subjects (see Tabs. 1 and 2). Sagittal first molar relationship (Class 1,2 and 3) was recorded for each subject and each side (right and left). Asymmetric molar classes were included in the data collection. The presence of a Clear Buccal Intercuspation was checked according to the clinical 


\begin{tabular}{|c|c|c|c|c|}
\hline 7 & $\begin{array}{l}\text { The distribution of SFM soft right: } \\
\text { ratio xz/xy right is the same across } \\
\text { categories of Asymmetric Molar } \\
\text { Class }(Y=1 \mathrm{~N}=2) \text {. }\end{array}$ & $\begin{array}{l}\text { Independent- } \\
\text { Samples } \\
\text { Mann- } \\
\text { Whitney U } \\
\text { Test }\end{array}$ & $.032^{1}$ & $\begin{array}{l}\text { Reject the } \\
\text { null } \\
\text { hypothesis }\end{array}$ \\
\hline 11 & $\begin{array}{l}\text { The distribution of SFM soft left: } \\
\text { sagittal area mm2 } \mathrm{xz} \text { right is the } \\
\text { same across categories of } \\
\text { Asymmetric Molar Class ( } \mathrm{Y}=1 \\
\mathrm{~N}=2 \text { ). }\end{array}$ & $\begin{array}{l}\text { Independent- } \\
\text { Samples } \\
\text { Mann- } \\
\text { Whitney U } \\
\text { Test }\end{array}$ & $.032^{1}$ & $\begin{array}{l}\text { Reject the } \\
\text { null the } \\
\text { hypothesis }\end{array}$ \\
\hline 21 & $\begin{array}{l}\text { The distribution of SFM soft } \\
\text { bilateral: sagittal area mm2 } \mathrm{xz} \text { right } \\
\text { is the same across categories of } \\
\text { Assmmmetric Molar Class }(\mathrm{Y}=1 \\
\mathrm{N}=2) \text {. }\end{array}$ & $\begin{array}{l}\text { Independent- } \\
\text { Samples } \\
\text { Mann- } \\
\text { Whitney U } \\
\text { Test }\end{array}$ &, $030^{1}$ & $\begin{array}{l}\text { Reject the } \\
\text { null } \\
\text { hypothesis }\end{array}$ \\
\hline 38 & $\begin{array}{l}\text { The distribution of SFM medium } \\
\text { right: ratio xz/xy left is the same } \\
\text { across categories of Asymmetric } \\
\text { Molar Class }(Y=1 \mathrm{~N}=2) \text {. }\end{array}$ & $\begin{array}{l}\text { Independent- } \\
\text { Samples } \\
\text { Mann- } \\
\text { Whitney U } \\
\text { Test }\end{array}$ & $.032^{1}$ & $\begin{array}{l}\text { Reject the } \\
\text { null } \\
\text { hypothesis. }\end{array}$ \\
\hline 47 & $\begin{array}{l}\text { The distribution of SFM medium } \\
\text { left: ratio } x z / x y \text { right is the same } \\
\text { across categories of Asymmetric } \\
\text { Molar Class }(Y=1 \mathrm{~N}=2) \text {. }\end{array}$ & $\begin{array}{l}\text { Independent- } \\
\text { Samples } \\
\text { Mann- } \\
\text { Whitney U } \\
\text { Test }\end{array}$ & $.039^{1}$ & $\begin{array}{l}\text { Reject the } \\
\text { null } \\
\text { hypothesis. }\end{array}$ \\
\hline 48 & $\begin{array}{l}\text { The distribution of SFM medium } \\
\text { left: ratio } x z / x y \text { left is the same } \\
\text { across categories of Asymmetric } \\
\text { Molar Class }(Y=1 \mathrm{~N}=2) \text {. }\end{array}$ & $\begin{array}{l}\text { Independent- } \\
\text { Samples } \\
\text { Mann- } \\
\text { Whitney U } \\
\text { Test }\end{array}$ & $.014^{1}$ & $\begin{array}{l}\text { Reject the } \\
\text { null } \\
\text { hypothesis }\end{array}$ \\
\hline 49 & $\begin{array}{l}\text { The distribution of SFM medium } \\
\text { left: ratio } x z / y z \text { right is the same } \\
\text { accoss categories of Asymmetric } \\
\text { Molar Class }(\mathrm{Y}=1 \mathrm{~N}=2) \text {. }\end{array}$ & $\begin{array}{l}\text { Independent- } \\
\text { Samples } \\
\text { Mann- } \\
\text { Whitney U } \\
\text { Test }\end{array}$ & $.025^{1}$ & $\begin{array}{l}\text { Reject the } \\
\text { null } \\
\text { hypothesis }\end{array}$ \\
\hline 57 & $\begin{array}{l}\text { The distribution of SFM medium } \\
\text { bilateral: ratio } x z / x y \text { right is the } \\
\text { same across categories of } \\
\text { Asymmetric Molar Class ( } \mathrm{Y}=1 \\
\mathrm{~N}=2 \text { ). }\end{array}$ & $\begin{array}{l}\text { Independent- } \\
\text { Samples } \\
\text { Mann- } \\
\text { Whitney U } \\
\text { Test }\end{array}$ & $.004^{1}$ & $\begin{array}{l}\text { Reject the } \\
\text { null } \\
\text { hypothesis. }\end{array}$ \\
\hline 58 & $\begin{array}{l}\text { The distribution of SFM medium } \\
\text { bilateral: ratio } x z / x y \text { left is the same } \\
\text { across categories of Asymmetric } \\
\text { Molar Class }(Y=1 \mathrm{~N}=2) \text {. }\end{array}$ & $\begin{array}{l}\text { Independent- } \\
\text { Samples } \\
\text { Mann- } \\
\text { Whitney U } \\
\text { Test }\end{array}$ & $.004^{1}$ & $\begin{array}{l}\text { Reject the } \\
\text { null } \\
\text { hypothesis. }\end{array}$ \\
\hline 59 & $\begin{array}{l}\text { The distribution of SFM medium } \\
\text { bilateral: ratio xz/yz right is the } \\
\text { same across categories of } \\
\text { Asymmetric Molar Class ( } \mathrm{Y}=1 \\
\mathrm{~N}=2 \text { ). }\end{array}$ & $\begin{array}{l}\text { Independent- } \\
\text { Samples } \\
\text { Mann- } \\
\text { Whitney U } \\
\text { Test }\end{array}$ & $.004^{1}$ & $\begin{array}{l}\text { Reject the } \\
\text { null } \\
\text { hypothesis. }\end{array}$ \\
\hline 50 & $\begin{array}{l}\text { The distribution of SFM medium } \\
\text { bilateral: ratio } x z / y z \text { left is the same } \\
\text { across categories of Asymmetric } \\
\text { Molar Class }(Y=1 \mathrm{~N}=2) \text {. }\end{array}$ & $\begin{array}{l}\text { Independent- } \\
\text { Samples } \\
\text { Mann- } \\
\text { Whitney U } \\
\text { Test }\end{array}$ & $.048^{1}$ & $\begin{array}{l}\text { Reject the } \\
\text { null } \\
\text { hypothesis. }\end{array}$ \\
\hline 67 & $\begin{array}{l}\text { The distribution of SFM hard right: } \\
\text { ratio xz/xy right is the same across } \\
\text { categories of Asymmetric Molar } \\
\text { Class }(Y=1 \mathrm{~N}=2) \text {. }\end{array}$ & $\begin{array}{l}\text { Independent- } \\
\text { Samples } \\
\text { Mann- } \\
\text { Whitney U } \\
\text { Test }\end{array}$ & ,0391 & $\begin{array}{l}\text { Reject the } \\
\text { null } \\
\text { hypothesis }\end{array}$ \\
\hline 68 & $\begin{array}{l}\text { The distribution of SFM hard right: } \\
\text { ratio } x z / x y \text { left is the same across } \\
\text { categories of Asymmetric Molar } \\
\text { Class }(Y=1 N=2) \text {. }\end{array}$ & $\begin{array}{l}\text { Independent- } \\
\text { Samples } \\
\text { Mann- } \\
\text { Whitney U } \\
\text { Test }\end{array}$ &, $005^{1}$ & $\begin{array}{l}\text { Reject the } \\
\text { nufl } \\
\text { hypothesis. }\end{array}$ \\
\hline
\end{tabular}

Figure 7. Mann-Whitney UTest results for differences in sagittal ( $x z$ plane of condylography) to transversal ( $y z$ and $x y$ planes) ratios of chewing tracings for SFM and NF in Asymmetric Molar Class (Y/N).

assessment of a distinct 1:2 vestibular relationship between upper and lower arches. Other sagittal and transversal intermaxillary dental relationships were recorded as well: open bite (when overbite $<0 \mathrm{~mm}$ ), deep bite (when overbite $>4 \mathrm{~mm}$ ), bilateral crossbite, monolateral crossbite, scissor bite. The presence and location of missing teeth and prosthodontic/ conservative restorations were recorded too. Occlusal surface characteristics were evaluated as Good, Average or Poor based on the investigators' assessment on overall tooth wear (Fig. 2). All subjects

\begin{tabular}{|c|c|c|c|c|}
\hline 77 & $\begin{array}{l}\text { The distribution of SFM hard left: } \\
\text { ratio } x z / x y \text { right is the same across } \\
\text { categories of Asymmetric Molar } \\
\text { Class }(Y=1 \mathrm{~N}=2) \text {. }\end{array}$ & $\begin{array}{l}\text { Independent- } \\
\text { Samples } \\
\text { Mann- } \\
\text { Whitney U } \\
\text { Test }\end{array}$ &, $003^{1}$ & $\begin{array}{l}\text { Reject the } \\
\text { null } \\
\text { hypothesis. }\end{array}$ \\
\hline 79 & $\begin{array}{l}\text { The distribution of SFM hard left: } \\
\text { ratio } x z / y z \text { right is the same across } \\
\text { categories of Asymmetric Molar } \\
\text { Class }(Y=1 \mathrm{~N}=2) \text {. }\end{array}$ & $\begin{array}{l}\text { Independent- } \\
\text { Samples } \\
\text { Mann- } \\
\text { Whitney U } \\
\text { Test }\end{array}$ & $.021^{1}$ & $\begin{array}{l}\text { Reject the } \\
\text { null } \\
\text { hypothesis. }\end{array}$ \\
\hline 81 & $\begin{array}{l}\text { The distribution of SFM hard } \\
\text { bilaterali: sagittal area mm2 } x z \text { right } \\
\text { is the same across categories of } \\
\text { Asymmetric Molar Class ( } Y=1 \\
\mathrm{~N}=2 \text { ). }\end{array}$ & $\begin{array}{l}\text { Independent- } \\
\text { Samples } \\
\text { Mann- } \\
\text { Whitney U } \\
\text { Test }\end{array}$ & $.031^{1}$ & $\begin{array}{l}\text { Reject the } \\
\text { null } \\
\text { hypothesis. }\end{array}$ \\
\hline 86 & $\begin{array}{l}\text { The distribution of SFM hard } \\
\text { bilateral: transversal area mm2 } x y \\
\text { left is the same across categories } \\
\text { of Asymmetric Molar Class ( } Y=1 \\
\mathrm{~N}=2 \text { ). }\end{array}$ & $\begin{array}{l}\text { Independent- } \\
\text { Samples } \\
\text { Mann- } \\
\text { Whitney U } \\
\text { Test }\end{array}$ &, $048^{1}$ & $\begin{array}{l}\text { Reject the } \\
\text { null } \\
\text { hypothesis. }\end{array}$ \\
\hline 87 & $\begin{array}{l}\text { The distribution of SFM hard } \\
\text { bilateral: ratio } x z / x y \text { right is the } \\
\text { same across categories of } \\
\text { Assmmetric Molar Class ( } Y=1 \\
\mathrm{~N}=2 \text { ). }\end{array}$ & $\begin{array}{l}\text { Independent- } \\
\text { Samples } \\
\text { Mann- } \\
\text { Whitney U } \\
\text { Test }\end{array}$ &, $031^{1}$ & $\begin{array}{l}\text { Reject the } \\
\text { null thesis. } \\
\text { hypothesis. }\end{array}$ \\
\hline 88 & $\begin{array}{l}\text { The distribution of SFM hard } \\
\text { bilateral: ratio } x z / x y \text { left is the same } \\
\text { across categories of Asymmetric } \\
\text { Molar Class }(Y=1 \mathrm{~N}=2) \text {. }\end{array}$ & $\begin{array}{l}\text { Independent- } \\
\text { Samples } \\
\text { Mann- } \\
\text { Whitney U } \\
\text { Test }\end{array}$ &, $009^{1}$ & $\begin{array}{l}\text { Reject the } \\
\text { null thesis. } \\
\text { hypothesis. }\end{array}$ \\
\hline 89 & $\begin{array}{l}\text { The distribution of SFM hard } \\
\text { bilateral: ratio } x z / y z \text { right is the } \\
\text { same across categories of } \\
\text { Asymmetric Molar Class ( }(Y=1 \\
\mathrm{N}=2 \text { ). }\end{array}$ & $\begin{array}{l}\text { Independent- } \\
\text { Samples } \\
\text { Mann- } \\
\text { Whitney U } \\
\text { Test }\end{array}$ & $.018^{1}$ & $\begin{array}{l}\text { Reject the } \\
\text { null thesis. } \\
\text { hypothesis. }\end{array}$ \\
\hline 117 & $\begin{array}{l}\text { The distribution of } \mathrm{NF} \text { salad } \\
\text { bilateral: ratio } \times z / x y \text { right is the } \\
\text { same across categories of } \\
\text { Asymmetric Molar Class ( } Y=1 \\
\mathrm{~N}=2 \text { ). }\end{array}$ & $\begin{array}{l}\text { Independent- } \\
\text { Samples } \\
\text { Mann- } \\
\text { Whitney U } \\
\text { Test }\end{array}$ & $.022^{1}$ & $\begin{array}{l}\text { Reject the } \\
\text { null } \\
\text { hypothesis. }\end{array}$ \\
\hline 118 & $\begin{array}{l}\text { The distribution of } \mathrm{NF} \text { salad } \\
\text { bilateral: ratio } x z / x y \text { left is the same } \\
\text { across categories of Asymmetric } \\
\text { Molar Class }(Y=1 \mathrm{~N}=2) \text {. }\end{array}$ & $\begin{array}{l}\text { Independent- } \\
\text { Samples } \\
\text { Mann- } \\
\text { Whitney U } \\
\text { Test }\end{array}$ &, $011^{1}$ & $\begin{array}{l}\text { Reject the } \\
\text { null } \\
\text { hypothesis. }\end{array}$ \\
\hline 177 & $\begin{array}{l}\text { The distribution of } \mathrm{NF} \text { nut bilateral: } \\
\text { ratio } x z / x y \text { right is the same across } \\
\text { categories of Asymmetric Molar } \\
\text { Class }(\mathrm{Y}=1 \mathrm{~N}=2) \text {. }\end{array}$ & $\begin{array}{l}\text { Independent- } \\
\text { Samples } \\
\text { Mann- } \\
\text { Whitney U } \\
\text { Test }\end{array}$ & $.011^{1}$ & $\begin{array}{l}\text { Reject the } \\
\text { null } \\
\text { hypothesis. }\end{array}$ \\
\hline 178 & $\begin{array}{l}\text { The distribution of } \mathrm{NF} \text { nut bilateral: } \\
\text { ratio } x z / \times y \text { left is the same across } \\
\text { categories of Assymmetric Molar } \\
\text { Class }(Y=1 \mathrm{~N}=2) \text {. }\end{array}$ & $\begin{array}{l}\text { Independent- } \\
\text { Samples } \\
\text { Mann- } \\
\text { Whitney U } \\
\text { Test }\end{array}$ &, $005^{1}$ & $\begin{array}{l}\text { Reject the } \\
\text { null } \\
\text { hypothesis. }\end{array}$ \\
\hline 179 & $\begin{array}{l}\text { The distribution of } \mathrm{NF} \text { nut bilateral: } \\
\text { ratio } x z / \mathrm{zz} \text { right is the same across } \\
\text { categories of Asymmetric Molar } \\
\text { Class }(\mathrm{Y}=1 \mathrm{~N}=2) \text {. }\end{array}$ & $\begin{array}{l}\text { Independent- } \\
\text { Samples } \\
\text { Mann- } \\
\text { Whitney U } \\
\text { Test }\end{array}$ & ,0111 & $\begin{array}{l}\text { Reject the } \\
\text { null } \\
\text { hypothesis. }\end{array}$ \\
\hline 180 & $\begin{array}{l}\text { The distribution of } N F \text { nut bilateral: } \\
\text { ratio } x z / y z \text { left is the same across } \\
\text { categories of Assymmetric Molar } \\
\text { Class }(Y=1 \mathrm{~N}=2) \text {. }\end{array}$ & $\begin{array}{l}\text { Independent- } \\
\text { Samples } \\
\text { Mann- } \\
\text { Whitney U } \\
\text { Test }\end{array}$ &, $022^{1}$ & $\begin{array}{l}\text { Reject the } \\
\text { nuff } \\
\text { hypothesis. }\end{array}$ \\
\hline
\end{tabular}

Figure 8. Mann-Whitney U Test results for differences in sagittal (xz plane of condylography) to transversal ( $y z$ and $x y$ planes) ratios of chewing tracings for SFM and NF in Asymmetric Molar Class (Y/N).

underwent a condylographic recording session during which a standard recording and a chewing recording were performed. The condylography was carried out by using an electronic recording system for jaw movements (Cadiax Diagnostic GAMMA Dental, ${ }^{\circledR} \mathrm{GAMMA}$ med. wiss. Fortbildungs $\mathrm{GmbH}$, Josef Brennerstr. 10, A-3400 Klosterneuburg, Austria). One trained investigator performed all recordings. A paraocclusal clutch was applied, the hinge axis was localized and classic condylographic recording of movements would take place before the chewing 
ITable 5. Quality of occlusal surfaces (right side).

\begin{tabular}{|l|c|}
\hline & \# of subjects \\
\hline Poor & 9 \\
\hline Average & 6 \\
\hline Good & 8 \\
\hline
\end{tabular}

recording session. A previously developed and described Standard Food was used in three different textures (soft, medium and hard) (A. Egger' Sohn, Süsswaren und Naturmittel $\mathrm{GmbH}$, Mellergasse 4, A-1230 Vienna, Austria). The shape of these jellies was cylindrical and the size was $10 \times 20 \mathrm{~mm}$ (Fig. 3).

The recordings were strictly performed for 18 seconds, on each side (right, left and bilateral chewing), for each texture of jellies and for each type of natural food. Eighteen seconds were mandatory because of the maximum recording time the software could host.

The participants were instructed to chew each food on the right side, on the left side and bilaterally, and break the food in as many pieces as possible without swallowing, since the food particles had to be collected at the end of each chewing cycle for separate evaluation.

A resting time of at least 30 seconds was allowed between recordings. The recording hardware was then removed, and the proband was asked to identify and score discomforts so that they could be collected and stored within the database.

For each proband the maximum ' $s$ ' displacement of the Temporomandibular Joint Hinge Axis during the 4 baseline movements and during the chewing sequences was taken from the software analysis for both right and left condyle in millimeters $(\mathrm{s}, \mathrm{mm})$. For each chewing sequence, for SFM and NF, the data in Table 3 were collected from the appropriate tool in the software and stored. For each chewing sequence, SFM and NF, the data in Table 4 were retrieved with the aid of the online tool SketchAndCalc ${ }^{\mathrm{TM}}$ (iCalc Inc, 2017 Elliott Dobbs, www.sketchandcalc.com) and used for further calculations (Fig. 4).

All Descriptive Statistics and Tests were carried out with IBM SPSS Statistics for Windows, Version 24.0 AND 25.0 Armonk, NY IBM Corp. (Released from 2016).

\section{RESULTS}

\subsection{Descriptive Analysis of Subjects}

There were 14 females (60.87\%) and 9 males (39.13\%). The subjects' age ranged from 18 to 64 years of age (mean age $37.74 \pm 12.53$ ).

The Molar Class for the right side was found to be Class 1 in $52.17 \%$ of subjects, Class 2 in 39.13\% and Class 3 in $8.70 \%$ of probands. For the left side, the percentages were $47.83 \%, 26.09 \%$ and $26.09 \%$ respectively. For both sides Molar Class 1 was nearly half of the total and an Asymmetric Molar Occlusion
ITable 6. Quality of occlusal surfaces (left side).

\begin{tabular}{|l|c|}
\hline & \# of subjects \\
\hline Poor & 8 \\
\hline Average & 8 \\
\hline Good & 7 \\
\hline
\end{tabular}

was detected in 5 subjects (21.7\%). See Gender distribution in Figs. 5 and 6. The Open Bite was present in 3 subjects overall (13\%), whereas Deep Bite was found in $30.4 \%$ of subjects (7 probands). The Open bite was present in 2 cases of Class 1 molar relationships (16.67\% of all class 1 ) and in 1 case $(11.11 \%)$ with molar class 2 , both for the right side. For the left side, the open bite was present in 2 cases (18.2\%) in Molar Class 1 and in 1 case (16.7\%) for class 2. No open bite was related to Molar Class 3 on either side. The Deep Bite was mostly present in Class 2 right side where it represented $44.44 \%$ of all class 2 subjects ( $25 \%$ for Class 1 right side, $0 \%$ for Class 3 right side).

For the left Molar Class 1, 2 and 3 the presence of the Deep Bite was present in $27.27 \%, 33.33 \%$ and 33.33\% of cases.

A bilateral Crossbite was detected in $17.39 \%$ of probands (4 cases) and a monolateral crossbite was present in 2 cases only (8.7\%). No proband had scissor bite.

The quality of the Occlusal Surfaces (Tabs. 5 and 6 ) was rated as poor for the right side on 9 counts (39.1\%), and on 8 counts for the left (34.8\%).

A Clear Buccal Intercuspation was found for 14 subjects (60.9\%). Missing Premolars were found in one proband only (4.3\%) with no edentulous gap between tooth 1.4 and tooth 1.6. Missing Molars were observed in 6 cases (26.1\%). Distal Restorations were present in 7 subjects $(30.43 \%)$.

\subsection{Statistical Analyses}

3.2.1. Condylographic Tracings for Working and NonWorking Sides with SFM and NF

For both food types, the working sides' tracings ( $\mathrm{s}$, $\mathrm{mm}$ ) were shorter than the non-working sides (SFM ws mean $4.9 \mathrm{~mm}$ nws $6.8 \mathrm{~mm}$; NF ws mean $3.6 \mathrm{~mm}$ nws $5.3 \mathrm{~mm}$; paired t test set at $95 \% \mathrm{Cl} \mathrm{p}=0.000$ for SFM and $p=0.000$ for NF). The difference by hardness on both ws and nws is not detectable. Nevertheless, all SFM compared to the NF s traits were significantly different, with SFM having larger displacements in mm (SFM s mean 5.75 mm; NF 4.56; paired t test set at $95 \% \mathrm{Cl} \mathrm{p}=0.000)$.

3.2.2. Condylographic Tracings' Distinctive Path Inclination $\mathrm{SCl}^{\circ}$ for Working and Non-Working Sides with SFM and NF

For the $\mathrm{SCl}^{\circ}$ (path inclination) SFM ws and nws were compared, with the nws showing a flatter inclination as expected (mean ws $=61.12^{\circ}$, mean nws $=53.31^{\circ}$ ), which was statistically different from the steeper inclination of the ws as tested with a paired t test 


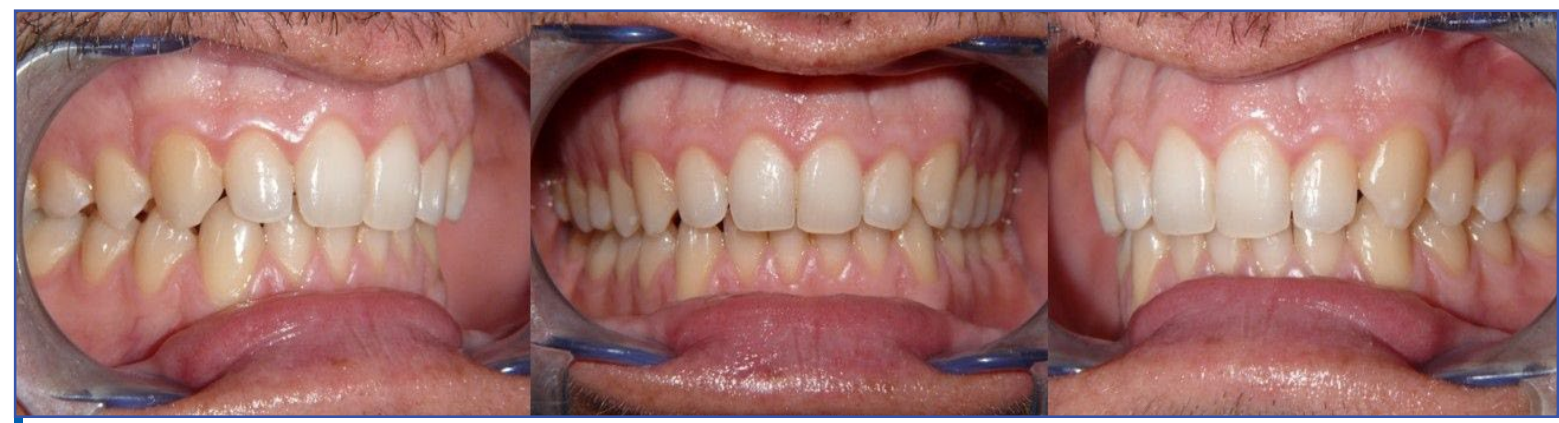

Figure 9. Male 31 yo, Asymmetric Molar Class (Right side Class 1, Left side Class 2).

set at $95 \% \mathrm{Cl}(p=0.000)$. Since the distribution of these data was not normal for $\mathrm{SCl}^{\circ} \mathrm{SFM}$ medium Left chewing and SFM hard Left chewing, a nonparametric test was also carried out (Wilcoxon Signed Rank Test with significance level at 0.05, $\mathrm{p}=0.01$ and 0.003 respectively). The NF chewing $\mathrm{SCl}^{\circ}$ were also compared for ws and nws by means of a parametric and a non-parametric test, since even here the normal distribution of data was not the case at all times. Both the paired t-test and the Wilcoxon Signed Rank Test allowed to highlight a significant difference in steepness of condylar path inclination. 3.2.3. Condylographic Distinctive Chewing Pattern for Working and Non-Working Sides with SFM and $\mathrm{NF}$

The presence of a Distinctive Chewing Pattern was tested against the Quality of Occlusion Surfaces Right and Left but no significant correlation was observed ( $x^{2} p=0.343$ right side $p=0.577$ left side). A significant correlation was observed instead for the variable Missing Molars and the absence of a Distinctive Pattern (Fisher Exact Test $p=0.006$ ). The variable Gender and Presence of Distal Restorations did not yield a statistically significant result (Fisher Exact Test $\mathrm{p}=0.064$ ).

3.2.4. Condylographic Chewing Tracings' Areas and Ratios with SFM and NF

The mere assessment of areas in $\mathrm{mm}^{2}$ showed few statistically significant results, but an observed tendency to have nws with bigger areas than ws for Molar Class 1 and 2.

However, assessment through ratios allowed the Authors to expressly identify the predominance of transversal movement during chewing over the sagittal one across all SFM and NF chewing (right side chewing, left and bilateral). Statistically significant results were retrieved for the variables Quality of Occlusion (poor, average, good Kruskal-Wallis max $p=0.42$ ), Bilateral Crossbite (Mann-Whitney $U$ $\max p=0.048$ ), Missing Molars (Mann-Whitney $U$ max $p=0.041$ ), Clear Buccal Intercuspation (MannWhitney U max $p=0.040$ ), Distal Restorations (MannWhitney $U \max p=0.041$ ) and most importantly Asymmetric Molar Class.

This latter variable in particular, gave significant results for all SFM hardness and for the NF too (for space reasons only these results are displayed in Figs. 7 and 8).

\section{DISCUSSION}

As there is increasing evidence indicating that oral health has an impact on Public Health issues, and not solely on Individual Health, it is important to understand and maintain the mastication tool properly fitted for its neurobiological objectives as well as nutritional ones.

What is expected from an 'ideal' mastication is, in this respect, of the utmost importance. If teeth are to be seen as refined, precise and sophisticated proprioceptors, then the scientific community's task is to test, assess and restore them accordingly. This is the assumption behind this work, which is an offspring of previous ones which aimed at studying human mastication quantitatively and qualitatively [22-26]. The Reader might want to know that other recorded condylographic parameters and chewing scores had to be kept out of this publication for space reasons (number of particles chewed, scores, number of chewing strokes, rotational angle $\mathrm{GAMMA}^{\circ}$ according to the different food hardness). The population of the present study encompassed diverse occlusal features, but it was a small one, nevertheless it allowed the Investigators to set some ground for new hypotheses for future studies, and make this an explorative study on mastication and its recording. Females showed more absence of a clear intercuspation as opposed to males, and they had a poorer occlusion, more occlusal restorations and, most importantly, less presence of a distinctive chewing pattern. Yet, the females here were the group with the most frequent 'ideal'Class 1 occlusion (81\%), and all Class 1s overall have $72 \%$ of clear buccal intercuspation. As elsewhere highlighted, this combination of findings suggests that the Molar Class alone is not a sufficient indicator at all for an ideal or functional mastication [48]. Monolateral Crossbite cases were too few to infer correlations. Condylography really fulfilled the task of showing geometrical features of working and non-working sides for SFM and NF: for both food types the working sides were in fact shorter than the non-working sides. This comes helpful in research settings in that SFM, which is not a vegetable but is still food, is generally chewed with the expected pattern that NF normally shows, but it has the potential to stress and highlight characteristics which small, easily chewed NFs may 


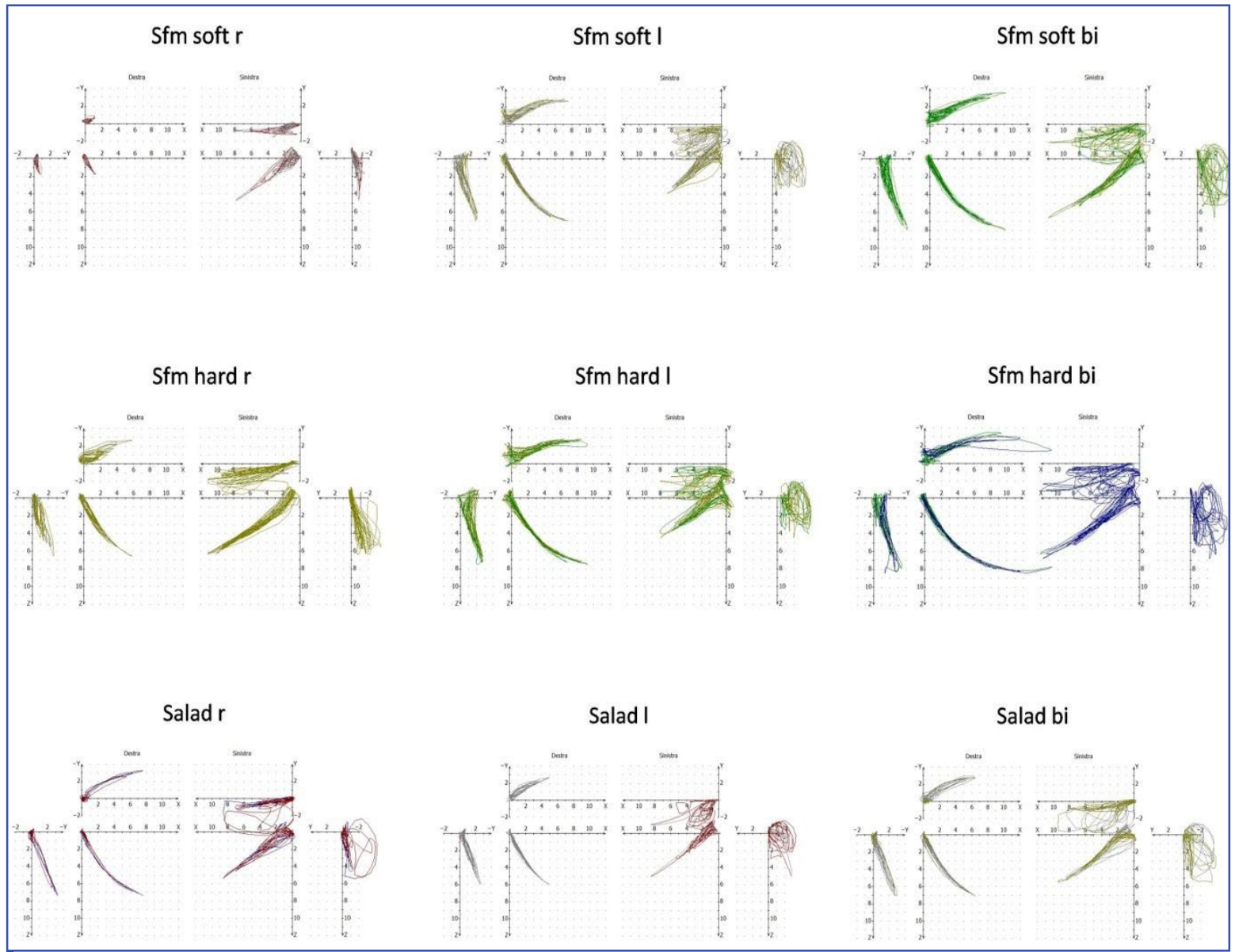

Figure 10. Condylographic Recording during chewing of SFM and NF (only soft and hard SFM, and salad leaf chewing are displayed for space reasons) by proband in Figure 9 . Non-harmonic left side tracings with a very wide transversal component can be observed for SFM and NF chewing.

not have the power to exhibit. Much like many other clinical tests which can be performed at rest, but are sometimes required to be performed under physical or drug-induced stress to really recreate a condition or provoke one, the SFM chewing test might prove the treadmill test for the masticatory system. The results with nuts and carrots have shown in fact that every proband can chew on them with no trouble regardless of the occlusal quality, missing teeth and so forth. One single salad leaf is instead more demanding, since it can be properly torn only when the occlusal quality is maintained, for it requires closeness of upper and lower teeth which get to slide on their buccal and lingual slopes. If these are lost then a grinding movement between flatter surfaces occurs and this sets the basis for a more horizontal/transversal movement rather than a vertical/sagittal one. All lengths 's' of the SFM sagittal tracings were numerically bigger than all lengths of NF sagittal tracings and this might be the effect of the properties of SFM (standard size for instance). For $\mathrm{SCl}^{\circ}$ (condylar path inclination), SFM ws and nws were compared, nws showing a flatter inclination as expected, which was statistically different from the steeper inclination of the ws. The same held true for NF. The assessment of the chewing tracings' areas was the most demanding and most interesting chapter in this explorative study. Not only were the single areas retrieved for all foods, all sides and all planes (sagittal, frontal and cranial), but ratios between the sagittal plane and the transversal planes were also calculated, so as to minimize the effect due to individual sizes, and enhance the more robust meaning of sagittal to transversal ratios. As the ratio decreases, both for the sagittal:frontal and the sagittal:cranial dimensions, then the transversal quantity of movement becomes predominant over the sagittal one. Graphical representation of areas in $\mathrm{mm}^{2}$, divided by ws and nws and molar class right and left, was difficult to interpret at a first glance and no particular difference or feature stood out. When the chewing data were assessed through the ratios one can see that the 'good' quality of the occlusion right had bigger nws ratios (more sagittal component) for SFM soft and medium (this difference was not visible for SFM hard), as compared to the average and poor right occlusions (more transversal component). A similar trend could be seen for the nws ratios for the left qualities of occlusion, but not for every single ratio and hardness of SFM.

The ws ratios were smaller in poor right occlusions as compared to the ws ratios of the the average and good occlusions, supporting the hypothesis that even in working sides there is a more transversal component in flatter occlusal qualities. The same could be seen for the left qualities of occlusion. 
Similarly, when looking at the NF ratios, the poor occlusions right and left had smaller ratios compared to average occlusion, but not as much compared to the good occlusion where differences were mostly seen in the sagittal: cranial plane ratios. This sagittal:cranial ratio looks especially useful when looking at differences in NF, since the 's' displacement is already significantly shorter in NF than SFM, and perhaps more understandable on the cranial plane instead of the frontal one. For a similar reason ws ratios in NF show little or inconsequent differences among the various occlusal qualities, since the range of the areas on working sides is already quite small in $\mathrm{mm}^{2}$. Another difference between the ratios can be detected between the ws ratios of SFM and NF in subjects who have distal restorations and subjects who do not have distal restorations (NF nut is the only food which does not show this as clearly), with the Distal Restoration Group displaying smaller ratios (therefore a more transversal component). The same observation could not be made for the nws. Probands without Clear Buccal Intercuspation display smaller ratios for $\mathrm{NF}$ in the nws than probands with Clear Buccal Intercuspation. Ws show the same difference but only in sagittal: cranial evaluation. The above-mentioned observations have been tested (for areas and ratios, for SFM and NF) and differences have been found to be statistically significant. All differences in the sagittal and transversal areas in $\mathrm{mm}^{2}$ provide food for thought in that they indicate a purely numerical size discrepancy which could hide or be related to other 'size' parameters not taken into account in this study. Anyway, it is the difference or even inversion of the sagittal to transversal ratios, in Bilateral Crossbite, Missing Molars and Asymmetric Molar Class subjects, that really supports the idea that these occlusal features and malocclusions are related to a higher transversal displacement during chewing cycles, usually with the non-working side performing very wide movements (see Figs. 9 and 10). The findings in this explorative study suggest a number of considerations. Transveral stability in occlusion (granted by one-to-two tooth contacts sagittally, and by lingual occlusion transversally) needs to be looked at and restored/provided for accordingly. The quality of occlusion is a crucial feature: restorative procedures which aim at restoring quadrants or single elements in flat occlusions need to be looked at critically. Missing and unreplaced molars correlate with dysfunctional chewing patterns. Molar Class has already shown little significance and therefore it is not a good indicator for describing malfunctions or chewing differences. Some of the unexpected chewing patterns may be due to undetected skeletal asymmetry of the cranial base which does not necessarily correlate with an asymmetry in molar class. SFM and condylographic recording can be exploited as a stress test for the detection of incapability in chewing stiff meats or other nutrient food.

\section{CONCLUSIONS}

As highlighted in previous works, the geriatric population is highly affected by cognitive impairment and more exposed to pureed, blended and mashed food. At times it is because dysphagia is present, however in many facilities prescription of pureed food is offered to many without real reasons behind it. MTF (Modified Texture Food) is often poorer in nutritional content and not very accepted and therefore eaten less despite the apparent easiness in swallowing it [49].

Like others, Dementia is a delicate Public Health issue in that it directly affects patients and families, it requires a very demanding set of measures to satisfy the need and quality of life of both, and it tackles many aspects of preventive medicine. Needless to say, it is a financial dilemma for many and it encompasses a very transversal series of medical specialties, odontology being one of the most recent. Prevention is crucial as medical therapy is at present unable to address Dementia, resulting in a frustrating series of events which lead to smaller chance of detecting other diseases, smaller response to treatments in general, reduced life expectancy and uncontrolled disease progression [6].

A better understanding of the significance and role of dental elements as singular units in neurological modulation could empower knowledge about dental risk factors and perhaps make them modifiable, and this would raise new awareness to be transferred to researchers, physicians and most importantly the population. Bearing this in mind, proper mastication should be guaranteed to avoid malnutrition in those populations where cognitive impairment has already occurred, and to at least maintain their general health status. Studies on the chewing efficiency of these very populations have shown that Dementia patients eat slowly and therefore less, have uncoordinated masticatory activities with chewing strokes accompanied by facial mimic movements, and most importantly that it is very hard to assess their chewing performance. At the same time, it is by now widely recognized that chewing positively affects cognitive functions with respect to memory and learning, and that masticatory hypofunction is independently related to cognitive impairment [50]. Mastication studies have historically been conducted by dental researchers to highlight features and risk factors related to Temporomandibular Disorders, to understand human stress-management strategies, or even to assess orthodontic treatments, full dentures, prosthodontic restorations and functions like speech and bruxism. More recent evidence on Public Health impact of mastication urges scientists to identify occlusal characteristics which interfere with a healthy masticatory function, so as to pinpoint preventive measures or minimize health impairments. The findings presented here are supported by the extensive previous works 
of authors who approached their research with different apparatuses. This study's aim was to identify a correlation between specific occlusal features and what is so far known about the characteristics of 'dysfunctional chewing patterns.' The results from chewing tests by means of a Standardized Food in combination with condylographic studies should be promoted in the future to better understand chewing patterns, but most importantly to make a statement concerning which occlusal characteristics are to be detected early, which are to be avoided in rehabilitation procedures, and which goal should occlusion therapy pursuit. In the near future, individual compensatory capabilities should not be called upon to excuse poor occlusal therapies, and other conditions within the psychosocial sphere should no longer justify a sudden or progressive onset of stomatognathic symptoms. This study's limitations are surely related to the small number of cases. The study design did not require a minimum number of occlusal patterns (such as monolateral crossbite for instance) and even though some differences were statistically significant, a higher number of cases, a more robust study design and a less numerous choice of outcomes might allow to draw more powerful conclusions and influence clinical work.

\section{CONFLICT OF INTEREST}

The authors declare no conflict of interest.

\section{ACKNOWLEDGMENTS}

The Authors wish to thank Dr. Eugenio Tanteri for providing hardware for the study.

\section{AUTHOR CONTRIBUTIONS}

GT: contributed to the study design, protocol, data gathering, analysis, manuscript preparation. CT: contributed to the study design and manuscript revision. GS: contributed to the concept, study design, analysis and interpretation of data.

\section{REFERENCES}

1. Mattila KJ, Nieminen MS, Valtonen VV, et al. Association between dental health and acute myocardial infarction. BMJ. 1989;298(6676):779-781. doi: 10.1136/bmj.298.6676.779. PMID: 2496855; PMCID: PMC1836063.

Google Scholar Scopus WoS

2. DeStefano F, Anda RF, Kahn HS, et al. Dental disease and risk of coronary heart disease and mortality. BMJ. 1993:306(6879):688691. doi: 10.1136/bmj.306.6879.688. PMID: 8471920; PMCID: PMC1677081.

Full text links CrossRef PubMed Google Scholar Scopus WoS 3. Liljestrand JM, Havulinna AS, Paju S, et al. Missing teeth predict incident cardiovascular events, diabetes, and death. J Dent Res. 2015;94(8):1055-1062. doi: 10.1177/0022034515586352. PMID: 25991651.

Full text links CrossRef PubMed Google Scholar Scopus WoS 4. Offenbacher S, Beck JD. Commentary: changing paradigms in the oral disease-systemic disease relationship. J Periodontol. 2014;85(6):761-764. doi: 10.1902/jop.2014.140115. PMID: 24875011.

Full text links CrossRef PubMed Google Scholar WoS 5. Shen T, Lv J, Wang L, et al. Association between tooth loss and dementia among older people: a meta-analysis. Int J Geriatr Psychiatry. 2016;31(8):953-955. doi: 10.1002/gps.4396. PMID: 26644219.

Full text links CrossRef PubMed Google Scholar Scopus WoS 6. Noble JM, Scarmeas N, Papapanou PN. Poor oral health as a chronic, potentially modifiable dementia risk factor: review of the literature. Curr Neurol Neurosci Rep. 2013;13(10):384. doi: 10.1007/ s11910-013-0384-x. PMID: 23963608; PMCID: PMC6526728. Full text links CrossRef PubMed Google Scholar Scopus WoS 7. Farahani RM, Simonian M, Hunter N. Blueprint of an ancestral neurosensory organ revealed in glial networks in human dental pulp. J Comp Neurol. 2011;519(16):3306-3326. doi: 10.1002/ cne.22701. PMID: 21681747.

Full text links CrossRef PubMed Google Scholar Scopus WoS 8. Chen $\mathrm{H}$, linuma M, Onozuka M, Kubo KY. Chewing maintains hippocampus-dependent cognitive function. Int J Med Sci. 2015;12(6):502-509. doi: 10.7150/ijms.11911. PMID: 26078711; PMCID: PMC4466515.

Full text links CrossRef PubMed Google Scholar Scopus WoS 9. Gibbs $\mathrm{CH}$, Mahan PE, Lundeen $\mathrm{HC}$, et al. Occlusal forces during chewing--influences of biting strength and food consistency. J Prosthet Dent. 1981;46(5):561-567. doi: 10.1016/0022-

3913(81)90247-x. PMID: 6946223.

Full text links CrossRef PubMed Google Scholar Scopus WoS
10. Gibbs $\mathrm{CH}$, Wickwire NA, Jacobson AP, et al. Comparison of typical chewing patterns in normal children and adults. J Am Dent Assoc. 1982;105(1):33-42. doi: 10.14219/jada. archive.1982.0073. PMID: 6955363.

Full text links CrossRef PubMed Google Scholar Scopus WoS 11. Felício CM, Melchior Mde O, Silva MA, Celeghini RM. [Masticatory performance in adults related to temporomandibular disorder and dental occlusion]. Pro Fono. 2007;19(2):151-158. Portuguese. doi: 10.1590/s010456872007000200003. PMID: 17710341.

PubMed Google Scholar

12. Piancino MG, Kyrkanides S. Understanding masticatory function in unilateral crossbites. John Wiley \& Sons Inc; 2016. ISBN: 9781118971871. doi:10.1002/9781118971901.

CrossRef Google Scholar Scopus WoS

13. Lewin A. Electrognathographics. An atlas for diagnostic procedures and interpretations. Berlin: Quintessence Publishing Co. Inc.; 1985. ISBN: 9780867151565.

14. Moss ML. A theoretical analysis of the functional matrix. Acta Biotheor. 1968;18(1):195-202. doi: 10.1007/BF01556727. PMID: 4984482.

Google Scholar

15. Kikui M, Ono T, Kokubo Y, et al. Relationship between metabolic syndrome and objective masticatory performance in a Japanese general population: the Suita study. J Dent. 2017;56:5357. doi: 10.1016/j.jdent.2016.10.014. PMID: 27793706. Full text links CrossRef PubMed Google Scholar Scopus WoS 16. Gambareli FR, Serra MD, Pereira LJ, Gaviao MB. Influence of measurement technique, test food, teeth and muscle force interactions in masticatory performance evaluation. Review Article. J Texture Stud. 2007;38(1):2-20. https://onlinelibrary.wiley. com/doi/full/10.1111/j.1745-4603.2007.00083.x CrossRef Google Scholar

17. Helkimo $\mathrm{E}$, Carlsson GE, Helkimo M. Chewing efficiency and state of dentition. A methodologic study. Acta Odontol Scand. 1978;36(1):33-41. doi: 10.3109/00016357809026364. PMID: 273364.

Full text links CrossRef PubMed Google Scholar Scopus

18. Kapur KK, Soman SD. Masticatory performance and efficiency in denture wearers. 1964. J Prosthet Dent. 2006;95(6):407-411. doi: 10.1016/j.prosdent.2006.03.012. PMID: 16765149.

Full text links CrossRef PubMed Google Scholar

19. Kimoto K, Garrett NR. Effect of mandibular ridge height on masticatory performance with mandibular conventional and implant-assisted overdentures. Int J Oral Maxillofac Implants. 2003;18(4):523-530. PMID: 12939003.

PubMed Google Scholar Scopus WoS 
20. Schneider G, Senger B. Clinical relevance of a simple fragmentation model to evaluate human masticatory performance. J Oral Rehabil. 2002;29(8):731-736. doi: 10.1046/j.1365-2842.2002.00967.x. PMID: 12220339. Full text links CrossRef PubMed Google Scholar Scopus WoS 21. Pocztaruk Rde L, Frasca LC, Rivaldo EG, et al. Protocol for production of a chewable material for masticatory function tests (Optocal - Brazilian version). Braz Oral Res. 2008;22(4):305-310. doi: 10.1590/s1806-83242008000400004. PMID: 19148384. Full text links CrossRef PubMed Google Scholar

22. Slavicek G, Soykher M, Gruber H, et al. A novel standard food model to analyze the individual parameters of human mastication. Int J Stomatol Occlusion Med. 2009;2(4):163-174. doi: 10.1007/s12548-009-0029-5.

CrossRef Google Scholar

23. Slavicek $G$, Soykher $M$, Gruber $H$, et al. [Case studies on the analysis of chewing part 1: Standard Analysis]. Stomatologie. 2009;106(7):119-129. German. doi: 10.1007/s00715-009-0099-4. 24. Slavicek G, Soykher M, Gruber H, et al. [Case studies on the analysis of chewing part 2: Special analysis options]. Stomatologie. 2009;106(8):137-148. German

doi: 10.1007/s00715-009-0103-z.

25. Slavicek G, Soykher M, Gruber H, et al. [Case studies on the analysis of chewing part 3: Analysis of cusp movements]. Stomatologie. 2010;107(1):1-7. German. doi: 10.1007/s00715-0100107-8.

26. Slavicek G, Soykher M, Soykher M, et al. Relevance of a standard food model in combination with electronic jaw movement recording on human mastication pattern analysis. Adv Biosci Biotechnol. 2010;1(02):68-78. doi: 10.4236/abb.2010.12011 CrossRef Google Scholar

27. Piehslinger E, Celar AG, Celar RM, Slavicek R. Computerized axiography: principles and methods. Cranio. 1991;9(4):344-355 doi: 10.1080/08869634.1991.11678382. PMID: 1820834. Full text links CrossRef Google Scholar WoS

28. Eke PI, Dye BA, Wei L, et al. Prevalence of periodontitis in adults in the United States: 2009 and 2010. J Dent Res. 2012;91(10):914-920. doi: 10.1177/0022034512457373. PMID: 22935673.

Full text links CrossRef PubMed Google Scholar Scopus WoS 29. Mojon P, Thomason JM, Walls AW. The impact of falling rates of edentulism. Int J Prosthodont. 2004;17(4):434-440. PMID: 15382779.

Full text links CrossRef PubMed Google Scholar Scopus WoS 30. WHO International. Duthey B. Alzheimer Disease and other Dementias. Background Paper 6.11. WHO; 2013.

Available at: http://www.who.int/medicines/areas/priority medicines/BP6 11Alzheimer.pdf

31. Okamoto N, Morikawa M, Tomioka K, et al. Association between tooth loss and the development of mild memory impairment in the elderly: the Fujiwara-kyo Study. J Alzheimers Dis. 2015;44(3):777-786. doi: 10.3233/JAD-141665. PMID: 25362033.

Full text links CrossRef PubMed Google Scholar Scopus WoS 32. Gatz M, Mortimer JA, Fratiglioni L, et al. Potentially modifiable risk factors for dementia in identical twins. Alzheimers Dement. 2006;2(2):110-117. doi: 10.1016/j.jalz.2006.01.002. PMID: 19595867.

Full text links CrossRef PubMed Google Scholar Scopus 33. Stein PS, Desrosiers M, Donegan SJ, et al. Tooth loss, dementia and neuropathology in the Nun study. J Am Dent Assoc. 2007;138(10):1314-1322; quiz 1381-1382. doi: 10.14219/jada. archive.2007.0046. PMID: 17908844

Full text links PubMed Google Scholar Scopus WoS 34. Takeuchi K, Izumi M, Furuta M, et al. Posterior teeth occlusion associated with cognitive function in nursing home older residents: a cross-sectional observational study. PLoS One. 2015;10(10):e0141737. doi: 10.1371/journal.pone.0141737. PMID: 26512900; PMCID: PMC4626072.

Full text links CrossRef PubMed Google Scholar Scopus WoS 35. Noble JM, Scarmeas N. Cognitive impairment. In: Lamster IB, Northridge ME, editors. Improving oral health for the elderly. New York: Springer Books; 2008.

36. Watanabe Y, Hirano H, Matsushita K. How masticatory function and periodontal disease relate to senile dementia. Jpn Dent Sci Rev. 2014;51(1):34-40. doi: 10.1016/j.jdsr.2014.09.002

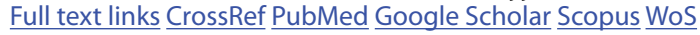

37. Batty GD, Li Q, Huxley R, et al. Oral disease in relation to future risk of dementia and cognitive decline: prospective cohort study based on the action in diabetes and vascular disease: Preterax and Diamicron modified-release controlled evaluation (ADVANCE) trial. Eur Psychiatry. 2013;28(1):49-52. doi: 10.1016/j. eurpsy.2011.07.005. PMID: 21964484; PMCID: PMC4170753. Full text links CrossRef PubMed Google Scholar WoS 38. Bergdahl M, Habib R, Bergdahl J, et al. Natural teeth and cognitive function in humans. Scand J Psychol. 2007;48(6):557565. doi: 10.1111/j.1467-9450.2007.00610.x. PMID: 18028078. Full text links CrossRef PubMed Google Scholar

39. Hansson $P$, Sunnegårdh-Grönberg K, Bergdahl J, et al.

Relationship between natural teeth and memory in a healthy elderly population. Eur J Oral Sci. 2013;121(4):333-340. doi: 10.1111/eos.12060. PMID: 23841785.

Full text links CrossRef PubMed Google Scholar Scopus WoS 40. Ishikawa T, Ikeda M, Matsumoto N, et al. A longitudinal study regarding conversion from mild memory impairment to dementia in a Japanese community. Int J Geriatr Psychiatry. 2006;21(2):134-139. doi: 10.1002/gps.1437. PMID: 16416466. Full text links CrossRef PubMed Google Scholar Scopus WoS 41. Stewart R, Stenman U, Hakeberg M, et al. Associations between oral health and risk of dementia in a 37-year followup study: the prospective population study of women in Gothenburg. J Am Geriatr Soc. 2015;63(1):100-105. doi: 10.1111 jgs.13194. PMID: 25597561.

Full text links CrossRef PubMed Google Scholar Scopus WoS 42. Onozuka M, Watanabe $K$, Fujita $M$, et al. Changes in the septohippocampal cholinergic system following removal of molar teeth in the aged SAMP8 mouse. Behav Brain Res. 2002;133(2):197-204. doi: 10.1016/s0166-4328(02)00006-2. PMID: 12110453.

Full text links CrossRef PubMed Google Scholar Scopus WoS 43. Watanabe K, Tonosaki K, Kawase T, et al. Evidence for involvement of dysfunctional teeth in the senile process in the hippocampus of SAMP8 mice. Exp Gerontol. 2001;36(2):283-295. doi: 10.1016/s0531-5565(00)00216-3. PMID: 11226743. Full text links CrossRef PubMed Google Scholar Scopus WoS 44. Mori D, Katayama T, Miyake $\mathrm{H}$, et al. Occlusal disharmony leads to learning deficits associated with decreased cellular proliferation in the hippocampal dentate gyrus of SAMP8 mice. Neurosci Lett. 2013 Feb 8;534:228-232. doi: 10.1016/j. neulet.2012.12.004. PMID: 23262093.

Full text links CrossRef PubMed Google Scholar Scopus WoS 45. Ichihashi Y, Arakawa Y, linuma M, et al. Occlusal disharmony attenuates glucocorticoid negative feedback in aged SAMP8 mice. Neurosci Lett. 2007;427(2):71-76. doi: 10.1016/j. neulet.2007.09.020. PMID: 17928141.

Full text links CrossRef PubMed Google Scholar Scopus WoS 46. Kubo KY, Yamada Y, linuma M, et al. Occlusal disharmony induces spatial memory impairment and hippocampal neuron degeneration via stress in SAMP8 mice. Neurosci Lett. 2007;414(2):188-191. doi: 10.1016/j.neulet.2006.12.020. PMID: 17207572.

Full text links CrossRef PubMed Google Scholar Scopus WoS 47. Elsig F, Schimmel M, Duvernay E, et al. Tooth loss, chewing efficiency and cognitive impairment in geriatric patients. Gerodontology. 2015;32(2):149-156. doi: 10.1111/ger.12079. PMID: 24128078

Full text links CrossRef PubMed Google Scholar Scopus WoS 48. Slavicek $G$. The influence of occlusion on masticatory efficiency considering relevant influencing factors. Stoma Edu J. 2020;7(3):197-207 https://doi.org/10.25241/stomaeduj.2020.7(3). art.6

Google Scholar

49. Keller H, Chambers L, Niezgoda H, Duizer L. Issues associated with the use of modified texture foods. J Nutr Health Aging. 2012;16(3):195-200. doi: 10.1007/s12603-011-0160-z. PMID: 22456772.

Full text links CrossRef PubMed Google Scholar

50. Teixeira FB, Pereira Fernandes Lde M, Noronha PA, et al. Masticatory deficiency as a risk factor for cognitive dysfunction. Int J Med Sci. 2014;11(2):209-214. doi: 10.7150/ijms.6801. PMID: 24465167; PMCID: PMC3894406.

Full text links $\underline{\text { CrossRef PubMed Google Scholar Scopus WoS }}$ 


\section{Giulia TANTERI}

MD, MSc, Specialist in Maxillofacial Surgery Private Practice - Studio Tanteri

Turin, Italy

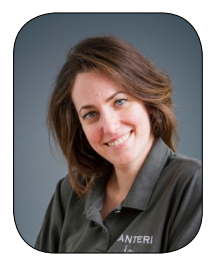

Dr. Giulia Tanteri, MD, MSc, graduated in Medicine and Surgery at the University of Turin, Turin, Italy where she subsequently completed her Oral and Maxillofacial Surgery specialization. Her activity is primarily dedicated to TMJ disorders diagnostics and treatment. Her research interests have focused on the instrumental assessment of the stomatognathic system and its rehabilitation, head and neck reconstructive surgery and oral surgery. She currently collaborates with the Steinbeis Transfer Institute for Biomedical Interdisciplinary Dentistry (Stuttgart, Germany) and works as a private practitioner in Turin, Italy.

\section{Questions}

\section{Tooth loss predicts the development of MMI among the elderly:}

$\square$ a. Absence of tooth loss and preservation of the patients' baseline status meant no increase in risk of MMl; ab. In case of periodontitis-induced tooth loss, cognitive function is worsened;

ac. If teeth are lost before the age of 50;

$\square \mathrm{d}$. None of the answers is correct.

\section{Mastication influences the activity in the cerebral cortex:}

a. Through blood flow increase especially in the prefrontal cortex and the hippocampus, where learning and memory performance reside;

b. Through increase of the number of neurons and synapses;

ac. Mastication and physical activity are rhythmic movements and have no beneficial effects on learning and spatial memory;

$\square$ d. Regardless of the presence of teeth.

\section{In geriatric evaluations:}

$\square$ a. Tooth count is the main predictive factor which should be assessed since patients are already being fed on mashed food;

bb. Tooth count and chewing performance should both be considered;

ac. Chewing performance only has relevance as a stress test for the Stomatognathic System;

$\square d$. Chewing performance and tooth count are both to be considered after the onset of dementia.

\section{Recording of a healthy chewing function should possess:}

$\square$ a. Symmetry between working and non-working sides;

b. A recognizable preferred chewing side;

口c. No specific pattern is relevant, as long as the subject is asymptomatic;

$\square$ d. Repetition, reproducibility and harmony in all projections, with a distinctive scheme for working and non-working sides. 